\title{
Unjuk Kinerja Alat Pasteurisasi pada Proses Pasteurisasi Madu: Studi Kasus PT Kembang Joyo Sriwijaya
}

\author{
Sasongko Aji Wibowo ${ }^{1 *}$, Anang Lastriyanto ${ }^{1}$, Erwan $^{2}$, Firman Jaya ${ }^{3}$, Jati Batoro ${ }^{4}$ \\ ${ }^{1}$ Jurusan Teknik Pertanian, Fakultas Teknologi Pertanian, Universitas Brawijaya, Malang \\ ${ }^{2}$ Fakultas Peternakan, Universitas Mataram, Nusa Tenggara Timur \\ ${ }^{3}$ Jurusan Teknologi Hasil Ternak, Fakultas Peternakan, Universitas Brawijaya, Malang \\ ${ }^{4}$ Fakultas Matematika Ilmu Pengetahuan Alam, Universitas Brawijaya, Malang \\ *Penulis korespondensi: Sasongko_aw@student.ub.ac.id
}

Histori artikel: diserahkan 20 Februari 2021, direviu 14 Maret 2021, direvisi 21 Maret 2021

\begin{abstract}
One of the post-harvest honey processing processes is the pasteurization process. Pasteurization is the initial stage of honey processing before evaporation. The high demand for honey in Indonesia requires that honey producing companies must use pasteurization tools with large capacities and do not damage the honey content. Honey will be damaged if the pasteurization temperature is more than $70^{\circ} \mathrm{C}$. In addition, the pasteurization process is also still a problem in the honey industry. Therefore it is necessary to make pasteurization tools with automatic and fast temperature control in the pasteurization process. The purpose of this study was to observe the rate of heat penetration into pasteurized honey material and the amount of honey weight pasteurized, then also measured changes in water content, viscosity, degree Brix, and density of density. From the results of measurements of heat penetration rates in pasteurization and conventional pasteurization devices, the difference in time duration on stoves 1,2, and 3 to increase the initial temperature of $35^{\circ} \mathrm{C}$ to $65^{\circ} \mathrm{C}$ respectively were 45,45 , and 42 minutes with a total of 101 honey, $22 \mathrm{~kg}$ while in conventional equipment takes 50 minutes to heat honey as much as $46,780 \mathrm{~kg}$. Gas consumption on stove 1 was $0.291 \mathrm{~g} /\left(\mathrm{kg}^{\circ} \mathrm{C}\right)$, stove 2 was 0.281 $\mathrm{g} /\left(\mathrm{kg}^{\circ} \mathrm{C}\right)$, stove 3 was $0.285 \mathrm{~g} /\left(\mathrm{kg}^{\circ} \mathrm{C}\right)$, whereas gas consumption on conventional stove was $0.272 \mathrm{~g} /\left(\mathrm{kg}^{\circ} \mathrm{C}\right)$. The results of measurements of water content, viscosity, Brix, and density of density before and after pasteurization were as follows $21.99 \%$, 4.835 poise, 63 obrix, $1.356 \mathrm{~kg} / \mathrm{m}^{3}$, and 19.82\%, 5.453 poise, $64 \mathrm{obrix}, 1.358 \mathrm{~kg} / \mathrm{m}^{3}$.
\end{abstract}

Keywords: honey, pasteurization, penetration, performance.

DOI : https://doi.org/10.18196/jqt.v2i2.10835

WEB : https://journal.umy.ac.id/index.php/qt/article/view/10835

\section{PENDAHULUAN}

\section{Latar Belakang}

Madu merupakan cairan manis yang menyerupai sirup yang dihasilkan oleh lebah madu dan memiliki rasa manis. Rasa manis pada madu berasal dari nektar yang dihisap lebah. Selain itu madu memiliki kandungan utama berupa glukosa dan fruktosa (Abu-Jdayil dkk., 2002). Komposisi madu meliputi $17-20 \%$ kadar air, $80-85 \%$ karbohidrat, dan $0,5-1 \%$ protein, asam amino, vitamin, dan mineral (Baglio, 2018). Madu termasuk produk yang baik untuk kesehatan dan memiliki potensi yang dapat digunakan sebagai produk pangan, farmasi, dan industri kosmetik.
Untuk mendapatkan madu yang berkualitas dan memiliki waktu penyimpanan yang lama, madu harus melalui proses pemanasan yang bertujuan untuk menghambat pertumbuhan organisme dan mengurangi kadar air (DImins, dkk., 2014). Pemanasan madu di atas $70^{\circ} \mathrm{C}$ tidak cocok karena menyebabkan degradasi senyawa bioaktif yang dapat mempengaruhi kualitas madu (Turhan, dkk., 2008). Pemanasan madu dengan suhu lebih dari $70^{\circ} \mathrm{C}$ juga tidak disarankan karena dapat menyebabkan perubahan rasa, warna, dan granulasi maduDisisi lain dapat mengurangi komponen bioaktif dan antioksidan serta menurunkan kualitas produk madu dan kandungan nutrisinya (Escriche, dkk., 2009). 
Dalam penelitian (Harjo, dkk., 2015) diketahui bahwa madu merupakan bahan makanan dengan kandungan enzim yang tinggi.Enzim merupakan protein yang terdenaturasi oleh beberapa faktor dari luar seperti dalam keadaan ph rendah atau ph terlalu tinggi, kemudian terkena panas atau logam berat (Raeymaekers, 2006). Beberapa jenis enzim yang paling penting dalam kandungan madu adalah diastase, invertase, glukosaoksidase, dan enzim yang aktif dalam fermentasi.White (1978), menyimpulkan bahwa aktivitas enzim diastase (Diastase Number $=\mathrm{DN}$ ) akan menurun seiring penambahan suhu, suhu maksimum yang disarankan untuk dilakukanya pasteurisasi adalah $70{ }^{\circ} \mathrm{C}$ karena pada suhu tersebut paruh hidup enzim diatase adalah 5,3jam.

Distribusi suhu pada alat pasteurisasi madu dilakukan dengan pemanasan dengan kompor high press burner. Kemudian akan terjadi penetrasi panas yang melewati tiga lapisan pada alat tersebut: lapisan pertama panci almunium, lapisan kedua berisi air, dan lapisan ketiga adalah panci yang berisi madu (Eshete \& Eshete, 2019). Madu yang berada di dalam panic lapisan ke dua, menerima distribusi panas yang berasal dari panas yang telah melewati ketiga lapisan alat tersebut.

Beberapa perushaan di Indonesia Pasteurisasi madu dilakukan dengan pemanassampai pada suhu $70^{\circ} \mathrm{C}$ kemudian dilakukan proses pengurangan kadar air dengan evaporasi vakum. Berdasarkan pengamatan yang telah dilakukan dalam proses penyimpanan, beberapa jenis madu yang telah dipanen kemudian di simpan dalam keadan kadar air diatas $22 \%$ akan terjadi pembuihan di bagian permukaan madu (Shelear, 2013).Proses pasteurisasi madu sebelum dilakukan evaporasi selain untuk mengurangi aktifitas fermentasi madu juga mempercepat proses evaporasi penurunan kadar air (Saxena, dkk., 2010)

Pada beberapa industri pengolahan madu di Indonesia, proses pasteurisasi madu menggunakan alat pemanaskonvensional. Pada alat tersebut, wadah penampung madu berbentuk 1 tabung keatas (vertikal) sehingga mempunyai kekurangan yaitu distribusi suhu selama proses pemanasan menjadi tidak rata antara bahan yang berada di dasar dekat dengan sumber panas (kompor) dan yang berada dibagian bawah permukaan. Suhu madu yang berada dekat dengan sumber panas akan menjadi lebih tinggi jika dibandingkan dengan madu yang berada di permukaan.pengukuran suhu madu dilakukan oleh operator setiap 20 menit sekali menggunakan thermometer raksa. Hal tersebut yang membuat suhu tidak terkontrol. Perbedaan tersebut akan mempengaruhi kualitas dan kandungan madu yang dihasilkan. Selain itu terjadi over heat suhu madu lebih dari $70^{\circ} \mathrm{C}$ ketika operator lalai tidak mematikan kompor pada saat suhu sudah mencapai $70^{\circ} \mathrm{C}$.

Salah satu pembuatan alat pasteurisasi yang sedang dikembangkan adalah alat pasteurisasi dengan menggunakan wadah penampung madudengan ketinggian tabung dalam yang disesuaikan dengan tinggi tabung luar sehingga memungkinkan pendistribusian panas merata. Penggunaan kedua tabung yang lebih presisi pada alat pasteurisasi diharapkan dapat mempengaruhi distribusi dan penetrasi suhu agar menjadi rata dan dapat mempersingkat waktu proses pemanasan. Selain itu perubahan kadar air, viskosistas, derajat brix, serta kerapatan massa jenis madu perlu diketahui untuk melihat perubahannya sebelum madu dipasteurisasi dan setelah dipasteurisasi.

Dari permasalahan tersebut perlu dilakukan unjuk kerja untuk alat pasteurisasi berkoloni (3 panci double jaket) guna mengetahui tolok ukur perbandingan pendistribusian dan penetrasi suhu kedalam bahan madu.

\section{Tujuan}

Tujuan dari penelitian ini adalah untuk mengamati laju penetrasi panaskedalam bahan madu yang dipasteurisasi antara alat konvensional dan alat pasteurisasi koloni, kapasitas kedua alat, dilakukan pengukuran perubahan kadar air, viskositas, derajat brix, dan kerapatan massa jenis terhadap kedua alat.

\section{METODE PENELITIAN}

\section{Alat dan Bahan}

Alat yang digunakan dalampenelitian ini adalah alat pasteurisasi berkoloni (3 panci double jaket) dilengkapi dengan sistem kontrol yang digunakan untuk mengatur suhu pada saat alat dioperasikan, sensor suhu termokopel 
type-K, moisture analyzer shimadzu MOC120 untuk mengukur kadar air, brix refraktometer untuk mengukur brix madu, viscometer NDJ-1S untuk mengukur kekentalan, piknometer untuk mengukur kerapatan masa jenis, timbangan digital serta alat tulis.

Bahan yang digunakan adalah madu murni dengan jenis madu hitam sebanyak $148 \mathrm{~kg}$ yang diperoleh dari PT Kembang Joyo Sriwijaya Malang dan gas LPG 4 buah. Penelitian dilakukan dilaboratorium Lastrindo Engginering kota Malang dan PT Kembang Joyo Sriwijaya Malang pada bulan Januari sampai Juli 2020.

\section{Metode Pengujian}

Pengujian dilakukan dengan mengamati laju penetrasi panas pada air dan madu murni. Pengujian tahap pertama menggunakan bahan air sebanyak $90 \mathrm{~kg}$ yang dimasukan ke dalam 3 wadah panci dengan kapasitas $200 \mathrm{~kg}$ masing masing seberat $30 \mathrm{~kg}$ per panci. Kemudian diukur masing masing suhu awal air sebelum bahan dipanaskan hingga suhu $60^{\circ} \mathrm{C}$ selanjutnya diamati dan dicatat laju penetrasi suhu setiap 5 menit, dan penimbangan berat gas dilakukan diawal dan diakhir waktu selama pemanasan untuk mengetahui konsumsi gas.

Tahap kedua pengujian menggunakan sampel madu sebanyak $148 \mathrm{~kg}$ yang dimasukan ke dalam masing-masing panci 1,2 dan 3 sebanyak $33,74 \mathrm{~kg}$ dengan perlakuan sama seperti tahap pertama dengan pemanasan suhu sampai $65^{\circ} \mathrm{C}$, pengambilan sampel dilakukan sebelum dan sesudah proses pasteurisasi.Alur pengoprasian alat ini sebagai berikut.

1) Persiapkan alat pasteurisasi, kemudian hubungkan masing-masing selang dari tabung gas 1,2, dan 3 kedalam input kotak kontrol gas 1,2, dan 3 .

2) Pasangkan juga masing masing selang output dari kotak kontrol 1,2, dan 3 menuju kompor 1,2 dan 3 .

3) Madu dimasukan kedalam 3 buah tabung dibagian dalam dengan setiap tabung sebanyak $33,73 \mathrm{~kg}$.

4) Air ditambahan kedalam tabung hingga penuh atau lebih tinggi dari permukaan madu yang dipanaskan.

5) Tutup setiap tabung bagian dalam karena sensor suhu ditempelkan memanjang pada tutup tabung, sehingga letak posisi sensor terdapat dibagian tengah tabung.

6) Hidupkan tombol power setiap sistem kontrol. kemudian tekan tombol setting point suhu yang akan digunakan pada setiap sistem kontrol. Suhu yang akan digunakan yaitu $70^{\circ} \mathrm{C}$.

7) Hidupkan setiap kompor 1,2 , dan 3 pada tekanan api kompor standar atau tidak terlalu besar.

8) Api kompor akan otomatis mengecil apabila suhu yang terbaca pada sensor sudah $70^{\circ} \mathrm{C}$ sehingga suhu akan tetap terjaga $70^{\circ} \mathrm{C}$, apabila suhu turun dibawah $70^{\circ} \mathrm{C}$ api kompor secara otomatis akan membesar

Sisa madu sebanyak 46,780 $\mathrm{kg}$ dimasukan kedalam alat pasteurisasi konvensional yang digunakan sebagai pembanding laju penetrasi panas serta konsumsi gas.

\section{Parameter Pengamatan}

\section{Laju penetrasi panas}

Laju penetrasi panas merupakan penerobosan atau perpindahan panas yang terjadi pada suatu material. Laju penetrasi sangat penting untuk diketahui dalam proses pasteurisasi. Dalam penelitian ini laju penetrasi ditentukan dengan persamaan (1), yaitu perbandingan kenaikan suhu dengan lama waktu yang dibutukan untuk pindah panas.

$\mathrm{LP}=\mathrm{T} / \mathrm{t}$

dimana:

LP $=$ Laju Penetrasi Panas $\left({ }^{\circ} \mathrm{C} /\right.$ menit $)$

$\mathrm{T}=\operatorname{Suhu}\left({ }^{\circ} \mathrm{C}\right)$

$\mathrm{t}=$ Waktu (menit)

\section{Konsumsi gas}

Pengamatan konsumsi gas perlu diketahui untuk mendapatkan jumlah gas yang dibutuhkan untuk memanaskan total bahan yang dipanaskan pada alat pasteurisasi. Pengukuran dilakukan dengan menimbang berat gas awal kemudian dikurangi berat gas akhir, dapat dilihat dalam persamaan 2 .

$K G=B G 1-B G n$ 
dimana:

$$
\begin{aligned}
& \mathrm{KG}=\text { Konsumsi Gas }(\mathrm{kg}) \\
& \mathrm{BG} 1=\text { Berat Gas Awal }(\mathrm{kg}) \\
& \mathrm{BGn}=\text { Berat Gas Akhir }(\mathrm{kg})
\end{aligned}
$$

\section{Kadar air}

Kadar air merupakan banyaknya air yang terkandung dalam bahan yang dinyatakan dalam persen. Kadar air juga salah satu karakteristik yang sangat penting pada bahan pangan, karena air dapat mempengaruhi penampakan, tekstur, dan cita rasa pada bahan pangan. Parameter kadar air digunakan untuk mengetahui berapa air yang hilang pada bahan madu yang dipasteurisasi. Pengukuran sampel kadar air menggunakan alat moisture analyzer.

Pengukuran kadar air di lakukan pada sampel yang diambil sebelum dan sesudah proses.

\section{Viskositas}

Viskositas merupakan ukuran kekentalan fluida yang menyatakan besar kecilnya gesekan dalam fluida. Semakin besar viskositas fluida, maka semakin sulit suatu fluida untuk mengalir dan juga menunjukan semakin sulit suatu benda bergerak di dalam fluida tersebut. Viskositas diukur menggunakan viskometer NDJ-1S untuk mengetahui perubahan kekentalan madu setelah dipasteurisasi. Dari manual book alat ukur viskometer NDJ-1S di tentukan pemilihan spindel nomor 2 dengan kecepatan 12 rpm digunakan untuk mengukur kekentalan madu.

\section{Brix}

Derajat Brix (system ${ }^{\circ} \mathrm{Bx}$ ) adalah kadar gula dari larutan berair. Satu derajat Brix adalah 1gram sukrosa dalam 100 gram larutan dan mewakili kekuatan solusi sebagai persentase berat $(\% \mathrm{~b} / \mathrm{b})$. Brix digunakan dalam system makanan untuk mengukur perkiraan jumlah gula (dalam buah-buahan, sayuran, jus, anggur, minuman ringan, dan dalam system manufaktur pati dan gula. Menurut SNI2018 tentang pengukuran kualitas madu, derajat brix diukur menggunakan brix refaktometer dengan skala 60-92 untuk nilai diketahui perbedaan brix sebelum dan sesudah dipasteurisasi.

\section{Kerapatan masa jenis}

Massa jenis merupakan pengukuran massa persatuan volume. Cara mengukur massa jenis pada umumnya dengan menimbang berat zat cair tersebut dan membaginya dengan volume zat cair yang terukur. Alat yang digunakan untuk mengukur kerapatan jenis madu adalah piknometer $50 \mathrm{ml}$, untuk mengetahui perbedaan nilai kerapatan masa jenis sebelum dan sesudah di pasteurisasi. Persamaan perhitungan kerapat masa jenis menggunakan persamaan 3 .

$\rho=(\mathrm{Ba}-\mathrm{Bb}) / \mathrm{v}$

Dimana:

kerapatan masa jenis $\left(\mathrm{kg} / \mathrm{m}^{3}\right)$

$\mathrm{Ba}=$ berat penimbangan piknometer dan bahan $(\mathrm{kg})$

$\mathrm{Bb}=$ berat penimbangan piknometer tanpa bahan $(\mathrm{kg})$

$\mathrm{v}=$ nilai volume piknometer yang digunakan $\left(\mathrm{m}^{3}\right)$.

\section{HASIL DAN PEMBAHASAN}

Pasteurisasi madu merupakan salah satu proses penting yang harus dilakukan dalam industri produksi madu, karena madu harus mengalami penyimpanan yang lama pada gudang penyimpanan madu. Kualitas madu dapat terganggu ketika melalui proses pemanasan karena komponen yang tidak stabil dan termolabil, penguraian vitamin dan kerusakan kandungan enzim terutama ketika dipanaskan lebih dari suhu $70^{\circ} \mathrm{C}$

Dalam aplikasi pengolahan madu komersial, panas adalah operasi yang penting dan diketahui memiliki potensi untuk menghilangkan mikroorganisme pembusuk, mempermudah pengemasan dan menunda kristalisasi. Umumnya alat pasteurisasi konvensional dengan desain tabung vertikal tinggi mengakibatkan kemampuan laju penetrasi panas tidak stabil yang mengakibatkan kerusakan pada kandungan madu karena panas dapat lebih dari $70^{\circ} \mathrm{C}$ (Gambar 1). Penggunaan alat pasteurisasi berkoloni (Gambar 2) dengan tinggi tabung dalam yang disesuaikan dengan tinggi tabung luar sehingga 

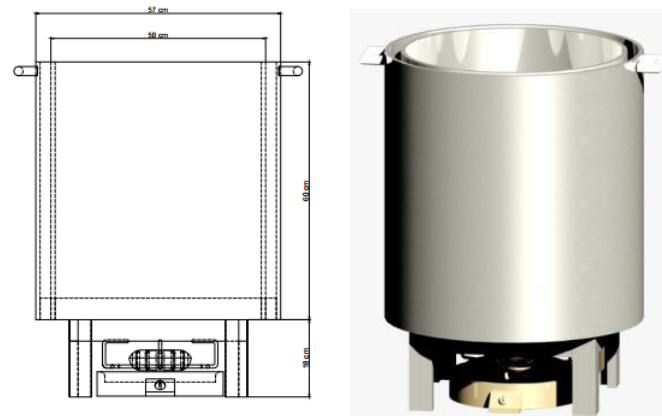

GAMBAR 1. Alat Pasteurisasi konvensional

pendistribusian panas dapat merata, kemudian alat tersebut dilengkapi dengan kontrol suhu otomatis (Gambar 3) supaya suhu bahan yang dipanaskan dapat terkontrol secara otomatis. Pada alat pasteurisasi konvensional yang ditunjukan pada Gambar 1, terdapat satu pasang tabung vertikal dengan tabung yang dibagian luar sebagai tempat air dan tabung bagian dalam sebagai tempat madu yang dipanaskan. Alat tersebut dilengkapi dengan satu kompor pemanas tanpa sistem kontrol.

Dalam pengoprasianya, setelah semua alat terpasang dan madu yang akan dipanaskan sudah dimasukan kedalam tabung bagian dalam kemudian dinyalakan kompor. Pengukuran suhu madu dilakukan oleh operator setiap 20 menit sekali menggunakan thermometer raksa. Hal tersebut yang membuat suhu tidak terkontrol, kemudian pengukuran suhu hanya dilakukan pada permukaan madu tidak sampai bagian tengah tabung sehingga suhu yang terbaca hanya bagian permukaan madu. Selain itu, terjadi over heat suhu madu lebih dari $70^{\circ} \mathrm{C}$ ketika operator lalai tidak mematikan kompor pada saat suhu sudah mencapai $70^{\circ} \mathrm{C}$.
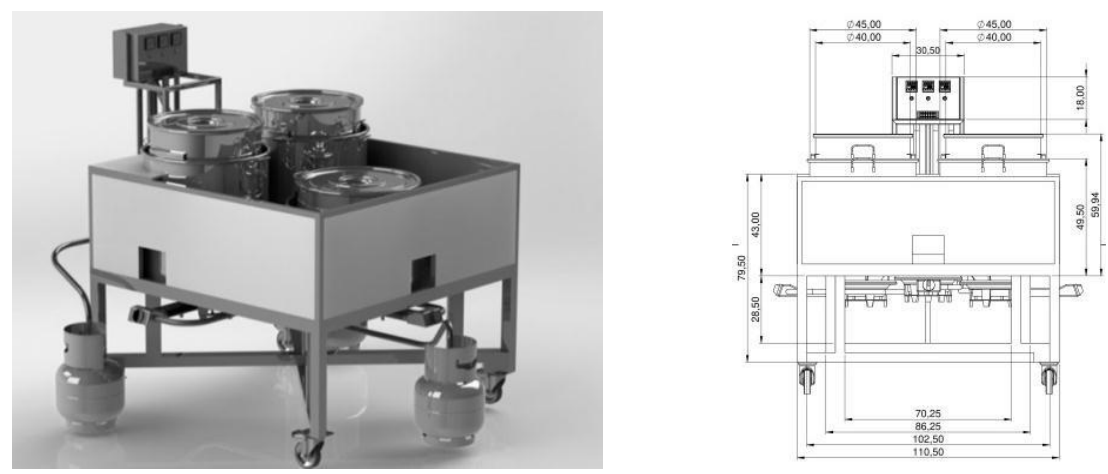

GAMBAR 2. Alat Pasteurisasi yang dirancang

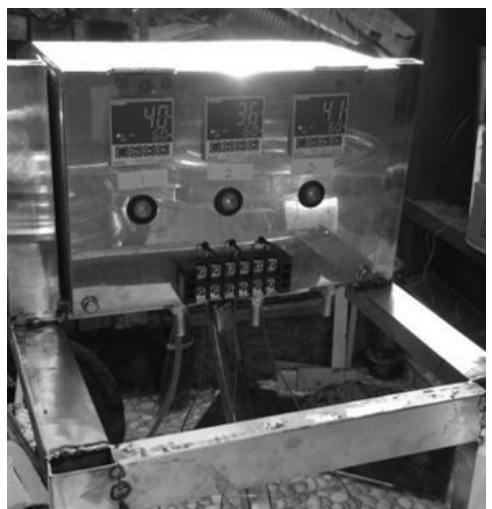

GAMBAR 3. Kotak sistem kontrol 


\section{Laju Penetrasi Suhu}

Dalam tahap awal penelitian ini, laju pemansan diuji dengan menggunakan bahan air, uji coba tahap awal laju penetrasi panas alat pasteurisasi menggunakan media bahan

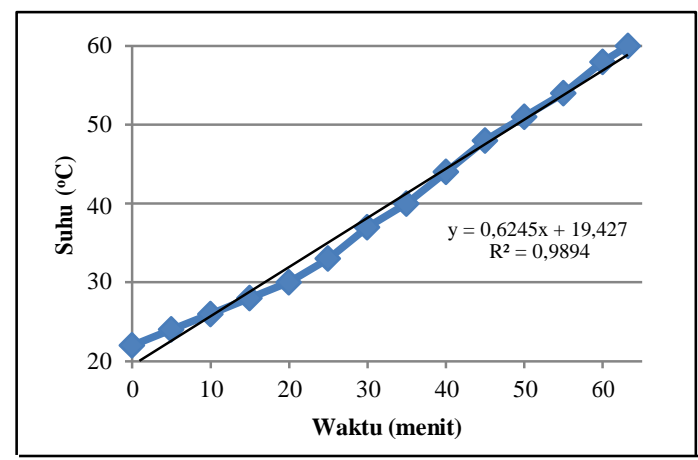

(a) air dilakukan dilaboratorium Lastrindo Enginering kota malang. Hasil laju penetrasi panas dengan media air diperoleh pada kompor 1, 2 dan 3 ditampilkan dalam bentuk grafik seperti ditunjukkan pada Gambar 4.

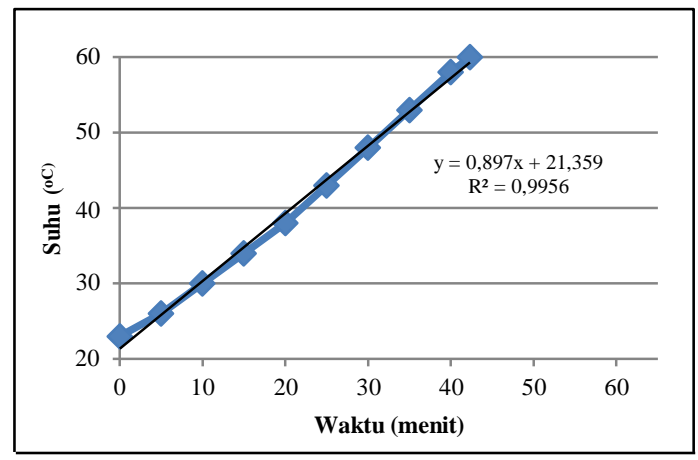

(b)

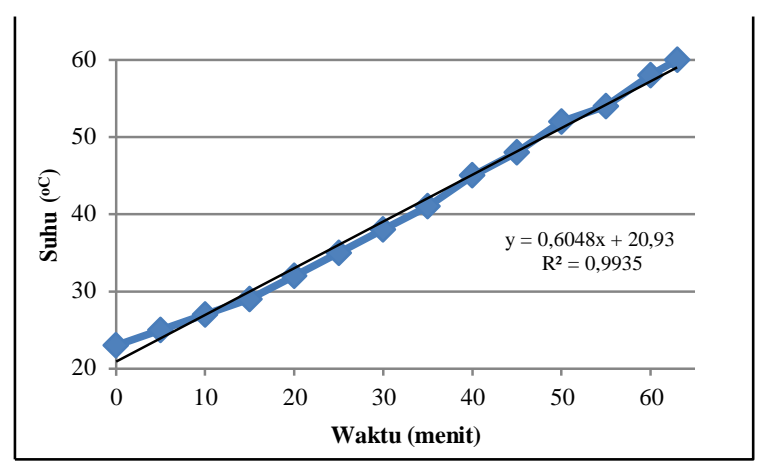

(c)

GAMBAR 4. Grafik laju penetrasi panas kenaikan suhu terhadap lama waktu: (a) kompor 1, (b) kompor 2, dan (c) kompor 3

Berdasarkan Gambar 4 hasil penetrasi pada kompor 1 diperoleh waktu selama 63 menit untuk menaikan suhu air awal $22^{\circ} \mathrm{C}$ sampai dengan suhu akhir $60^{\circ} \mathrm{C}$. Pada kompor 2 di peroleh waktu yang lebih singkat yaitu 42 menit untuk menaikan suhu air awal $23^{\circ} \mathrm{C}$ sampai dengan suhu akhir $60^{\circ} \mathrm{C}$ hal tersebut dikarenakan posisi panic terdapat dibagian tengah antara kompor 1 dan kompor 3 . Sedangkan pada kompor ke 3 diperoleh waktu selama 63 menit untuk menaikan suhu air awal $23^{\circ} \mathrm{C}$ sampai dengan suhu akhir $60^{\circ} \mathrm{C}$.

Tahap selanjutnya pengujian dilakukan menggunakan bahan madu jenis madu hitam sebanyak $148 \mathrm{~kg}$ yang berlokasi di PT Kembang Joyo Sriwijaya malang. Bahan madu sebanyak 101,22 kg dimasukan kedalam masing-masing tabung alat pasteurisasi 1, 2 dan 3 berturut turut sebanyak $33,74 \mathrm{~kg}$. kemudian madu di ukur suhu awal dan suhu akhir penetrasi. Laju penetrasi panas diukur dari suhu awal hingga suhu akhir penetrasi. Sampel madu diambil sebelum dan sesudah dilakukan pasteurisasi untuk di ukur kadar air, viskositas, brix dan perubahan kerapatan masa jenis madu. Kemudian untuk alat pesteurisasi konvensional juga digunakan bahan madu sebanyak 46,780 kg kemudian diukur suhu awal dan suhu akhir pasteurisasi dan diamati suhu laju penetrasi panas. Hasil laju penetrasi panas dengan bahan madu diperoleh pada kompor 1, 2, 3 dan konvensional ditampilkan dalam bentuk grafik sebagai berikut. 


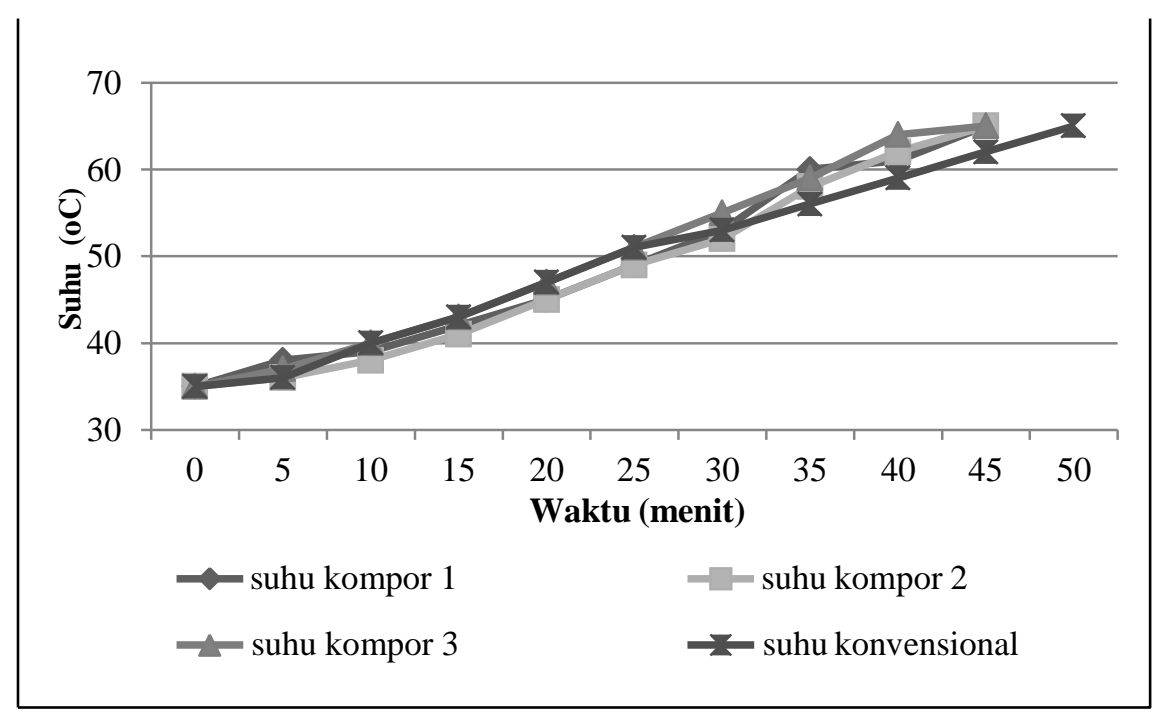

GAMBAR 5. Grafik laju penetrasi panas kenaikan suhu terhadap lama waktu dengan bahan madu hitam

TABEL 1. Nilai laju penetrasi panas.

\begin{tabular}{clc}
\hline No. & \multicolumn{1}{c}{ Kompor } & Nilai $\left({ }^{\mathbf{0}} \mathbf{C} /\right.$ Menit $)$ \\
\hline 1 & Kompor 1 & 0,6945 \\
\hline 2 & Kompor 2 & 0,7139 \\
\hline 3 & Kompor 3 & 0,7433 \\
\hline 4 & konvensional & 0,6235 \\
\hline
\end{tabular}

Dari Grafik laju penetrasi panas Gambar 5. dapat dilihat perbedaan lama waktu yang terjadi pada kompor 1,2, dan 3 untuk menaikan suhu awal $35^{\circ} \mathrm{C}$ hingga $65^{\circ} \mathrm{C}$ berturut turut adalah 45,45 , dan 42 menit sedangkan pada alat konvensional membutuhkan waktu selama 50 menit untuk menaikan suhu sampai $65^{\circ} \mathrm{C}$, namun suhu tersebut yang terbaca pada bagian bawah tabung konvensional, ketika sensor suhu diukur pada bagian atas mendekati permukaan bahan madu yang dipanaskan suhu yang terbaca pada sensor masih $45^{\circ} \mathrm{C}$. Penggunaan suhu panas madu di atas $70^{\circ} \mathrm{C}$ tidak dizinkan karena menyebabkan degradasi senyawa bioaktif yang dapat mempengaruhi kualitas madu, sehingga pada kompor konvensional ketika dipanaskan lebih lama untuk menaikan suhu $65^{\circ} \mathrm{C}$ pada bahan yang terdapat di bagian atas tabung akan menyebabkan kenaikan suhu lebih tinggi di bagian dasar pada tabung, sehingga dapat merusak senyawa bioaktif dan bahkan berbentuk caramel (Turhan et al., 2008).

Pengukuran Konsumsi Gas, Kadar Air, Viskositas, Brix, dan Kerapatan Masa Jenis Sebelum dan Sesudah dilakukan Pasteurisasi.

Setelah diketahui konsumsi gas (kg) berdasarkan persamaan (1) selanjutnya di lakukan perhitungan konsumsi gas spesifik dengan mengukur berat gas awal di kurang gas akhir dibagi suhu akhir dikurang suhu awal kemudian dibagi jumlah berat bahan madu yang dipanaskan. Konsumsi gas pada masing masing kompor ditampilkan pada Tabel 2.

TABEL 2. Konsumsi LPG spesifik pada kompor 1,2,3 dan konvensional

\begin{tabular}{clc}
\hline No. & \multicolumn{1}{c}{ Kompor } & Konsumsi LPG g/(kg $\mathbf{C})$ \\
\hline 1 & Konsumsi gas kompor 1 & 0,291 \\
\hline 2 & Konsumsi gas kompor 2 & 0,280 \\
\hline 3 & Konsumsi gas kompor 3 & 0,285 \\
\hline 4 & Konsumsi gas konvensional & 0,272 \\
\hline
\end{tabular}


Dari perhitungan konsumsi gas spesifik diperoleh hasil konsumsi gas pada masing masing kompor adalah sebagai berikut, diketahui konsumsi gas pada kompor 1 adalah $0,291 \mathrm{~g} /\left(\mathrm{kg}^{\circ} \mathrm{C}\right)$, kompor 2 adalah 0,281 $\mathrm{g} /\left(\mathrm{kg}^{\circ} \mathrm{C}\right)$, kompor 3 adalah $0,285 \mathrm{~g} /\left(\mathrm{kg}^{\circ} \mathrm{C}\right)$, ketiga kompor tersebut rata-rata memilik nilai yang hampir sama, sedangkan konsumsi gas pada kompor konvensional yaitu 0,272 $\mathrm{g} /\left(\mathrm{kg}^{\circ} \mathrm{C}\right)$. Dari hasil konsumsi gas pada kompor konvensional dan alat pasteurisasi tidak menunjukan perbedaan yang signifikan, tetapi lama waktu pemanasan berbeda hal tersebut dikarenakan posisi ketiga panci saling berdekatan, sehingga antara satu panci dengan panci yang lainya saling berbagi panas antara satu panci dengan panci yang lainya.

Pada sampel yang diambil sebelum dan setelah proses pasteurisasi dilakukan pengukuran kadar air, viskositas, brix dan kerapatan masa jenis. Hasil pengukuran ditampilkan pada Tabel 3.

TABEL 3. Pengukuran kadar air, viskositas, brix dan kerapatan masa jenis pada madu hitam sebelum dan sesudah dipasteurisasi pada alat pasteurisasi koloni.

\begin{tabular}{clcc}
\hline No. & \multicolumn{1}{c}{ Pengukuran } & Sebelum pasteurisasi & Sesudah pasteurisasi \\
\hline 1 & Kadar Air $(\%)$ & 21,99 & 19,82 \\
\hline 2 & Viskositas (poise) & 4,835 & 5,453 \\
\hline 3 & Brix (brix) & 63 & 64 \\
\hline 4 & $\begin{array}{l}\text { Kerapatan Massa Jenis } \\
\left(\mathrm{kg} / \mathrm{m}^{3}\right)\end{array}$ & 1,356 & 1,358 \\
\hline
\end{tabular}

TABEL 4. Pengukuran kadar air, viskositas, brix dan kerapatan masa jenis pada madu hitam sebelum dan sesudah dipasteurisasi pada alat pasteurisasi konvensional.

\begin{tabular}{clcc}
\hline No. & \multicolumn{1}{c}{ Pengukuran } & Sebelum pasteurisasi & Sesudah pasteurisasi \\
\hline 1 & Kadar Air $(\%)$ & 21,99 & 20 \\
\hline 2 & Viskositas (poise) & 4,835 & 5,424 \\
\hline 3 & Brix (brix) & 63 & 64 \\
\hline 4 & Kerapatan Massa Jenis $\left(\mathrm{kg} / \mathrm{m}^{3}\right)$ & 1,356 & 1,342 \\
\hline
\end{tabular}

Tabel 4 menunjukan perbedaan nilai kadar air, viskosistas, brix dan kerapatan massa jenis pada madu hitam sebelum dan sesudah dipasteurisasi pada alat pasteurisasi koloni. Dapat diketahui perubahan kadar air pada madu sebelum dipasteurisasi adalah 21,99\% dan sesudah di pasteurisasi adalah 19,82\%. Pada kekentalan madu juga mengalami perubahan nilai viskositasnya setelah madu di pasteurisasi yaitu 4,835 poise sebelum dipasteurisasi dan naik menjadi 5,453 poise sesudah dipasteurisasi pengukuran viskositas menggunakan viscometer NDJ-1S. selanjutnya pada derajat brix madu juga mengalami kenaikan yaitu dari 63 derajat brix menjadi 64 derajat brix, pengukuran derajat brix menggunakan refraktometer skala 60-90\%. Sedangkan kerapatan masa jenis mengalami sedikit kenaikan yaitu $1,356 \mathrm{~kg} / \mathrm{m}^{3}$ sebelum dipasteurisasi menjadi $1,358 \mathrm{~kg} / \mathrm{m}^{3}$ hanya mengalami perubahan $0,002 \mathrm{~kg} / \mathrm{m}^{3}$.
Sedangkan pada Tabel 5 ditunjukan perbedaan nilai kadar air, viskosistas, brix dan kerapatan massa jenis pada madu hitam sebelum dan sesudah dipasteurisasi pada alat pasteurisasi konvensional.

\section{KESIMPULAN}

Dari hasil penelitian dapat diketahui bahwa perbandingan laju penetrasi panas antara alat pasteurisasi 3 kompor dengan alat pasteurisasi konvensional mengalami perbedaan diantaranya:

1) Terjadi perbedaan lama waktu pemanasan yang terjadi pada kompor 1,2, dan 3 dengan total madu sebanyak $101,22 \mathrm{~kg}$ sedangkan pada alat konvensional membutuhkan waktu selama 50 menit untuk memanaskan madu sebanyak $46,780 \mathrm{~kg}$.

2) Konsumsi gas pada ketiga kompor tersebut rata rata memilik nilai yang hampir sama, 
sedangkan konsumsi gas pada kompor konvensional yaitu $0,272 \mathrm{~g} /\left(\mathrm{kg}^{\circ} \mathrm{C}\right)$.

3) Pengukuran perubahan kadar air, viskositas, brix dan kerapatan masa jenis sebelum dan sesudah dilakukan pasteurisasi pada alat pasteurisasi juga mengalami perubahan.

\section{UCAPAN TERIMAKASIH}

Ucapan terimakasih yang sebesar-besarnya diberikan kepada Lembaga Pengelola Dana Pendidikan (LPDP) yang telah membiayai seluruh kegiatan penelitian.

\section{DAFTAR PUSTAKA}

Abu-Jdayil, B., Ghzawi, A. A.-M., Al-Malah, K. I. M. \& Zaitoun, S. 2002. Heat Effect on Rheology of Light- and DarkColored Honey. Journal of Food Engineering,51(1),33-38. https://doi.org/10.1016/S02608774(01)00034-6

Baglio, E. 2018. Chemistry and Technology of Honey Production. In Salvatore Parisi (Ed.), Honey: Processing Techniques and Treatments $\left(1^{\text {st }} \quad\right.$ ed. $)$. https://doi.org/10.1007/978-3-31965751-6

DImins, F., Mikelsone, V., Kuka, P., \& Jefremovs, A. Ni. 2014. Effect of Different Types of Heat Treatment on Invertase Activity in Honey. Foodbalt, 2(1),13-18. https://doi.org/10.13140/2.1.5172.1605

Escriche, I., Visquert, M., Juan-Borrás, M., \& Fito, P. 2009. Influence of Simulated Industrial Thermal Treatments on The Volatile Fractions of Different Varieties of Honey. Food Chemistry, 112(2), 329338.

https://doi.org/10.1016/j.foodchem.2008 .05 .068
Eshete, Y., \& Eshete, T. 2019. A Review on the Effect of Processing Temperature and Time duration on Commercial Honey Quality. Madridge Journal of Food Technology, 4(1), 158-162. https://doi.org/10.18689/mjft-1000124

Harjo, S. S. T., Radiati, L. E., \& Rosyidi, D. 2015. Perbandingan Madu Karet dan Madu Rambutan Berdasarkan Kadar Air, Aktivitas Enzim Diastase dan Hidroximetilfurfural (HMF). Jurnal Ilmu Dan Teknologi Hasil Ternak, 10(1), 1821. https://doi.org/10.21776/ub.jitek.2015.01 0.01 .3

Raeymaekers, B. 2006. A Prospective Biomonitoring Campaign With Honey Bees in a District of Upper-Bavaria (Germany). Environmental Monitoring and Assessment, 116(1) ,233-243. https://doi.org/10.1007/s10661-0067389-8

Saxena, S., Gautam, S., \& Sharma, A. 2010. Physical, Biochemical and Antioxidant Properties of Some Indian Honeys. Food Chemistry, 118(2), 391-397. https://doi.org/10.1016/j.foodchem.2009. 05.001

Shelear, H. H. 2013. Effect of Storage and Processing Temperatures on Honey Quality. Journal of Babylon:Pure and Applied Sciences, 21(6), 2244-2253. Retrieved from

Turhan, I., Tetik, N., Karhan, M., Gurel, F., \& Reyhan Tavukcuoglu, H. 2008. Quality of Honeys Influenced By Thermal Treatment. Food Science and Technology, 41(8), 1396-1399. https://doi.org/10.1016/j.lwt.2007.09.008

White, J. W. 1978. Honey. Advances in Food Research,24(C),287-374. https://doi.org/10.1016/S00652628(08)60160-3 